\title{
The cardiovascular disorders and prognostic cardiac biomarkers in COVID-19
}

\author{
Xingjuan Shi ${ }^{1} \mathbb{D} \cdot$ Mengying Chen ${ }^{1} \cdot$ Yu Zhang $^{1}$
}

Received: 20 October 2020 / Accepted: 11 January 2021 / Published online: 22 January 2021

(c) The Author(s), under exclusive licence to Springer Nature B.V. part of Springer Nature 2021

\begin{abstract}
Severe acute respiratory syndrome coronavirus 2 (SARS-CoV-2) leads to the outbreak of coronavirus disease 2019 (COVID19), a worldwide epidemic disease affecting increasing number of patients. Although the virus primarily targets respiratory system, cardiovascular involvement has been reported in accumulating studies. In this review, we first describe the cardiac disorders in human with various types of $\mathrm{CoV}$ infection, and in animals infected with coronavirus. Particularly, we will focus on the association of cardiovascular disorders upon SARS-CoV-2 infection, and prognostic cardiac biomarkers in COVID-19. Besides, we will discuss the possible mechanisms underlying cardiac injury resulted from SARS-CoV-2 infection including direct myocardial injury caused by viral infection, reduced level of ACE2, and inflammatory response during infection. Improved understandings of cardiac disorders associated with COVID-19 might predict clinical outcome and provide insights into more rational treatment responses in clinical practice.
\end{abstract}

Keywords COVID-19 $\cdot$ Cardiovascular disorders $\cdot$ Hs-cTnI $\cdot$ NT-proBNP $\cdot$ Prognosis

\section{Introduction}

Severe acute respiratory syndrome coronavirus 2 (SARS$\mathrm{CoV}-2$ ) brings out the outbreak of a worldwide epidemic disease coronavirus disease 2019 (COVID-19). COVID-19 exhibits complex clinical symptoms, including moderate upper respiratory disease, serious viral pneumonia, systemic inflammatory syndrome and death [1]. SARS-CoV-2 primarily targets the respiratory system, however cardiovascular involvement has been reported in multiple studies. Some SARS-CoV-2-positive patients experience cardiac signs, for example aching in the chest and stuffiness or palpitation rather than respiratory problems [2].

It has been reported that cardiovascular complications of influenza and coronavirus infection including myocarditis, myocardial infarction and heart failure exert great impact

Supplementary Information The online version of this article (https://doi.org/10.1007/s11033-021-06148-9) contains supplementary material, which is available to authorized users.

Xingjuan Shi

xingjuanshi@seu.edu.cn

1 School of Life Science and Technology, Key Laboratory of Developmental Genes and Human Disease, Southeast University, Nanjing 210096, China on mortality during previous epidemics [3]. Patients with preexisting cardiovascular disease demonstrated adverse outcomes including arrhythmia and sudden cardiac health in previous coronavirus epidemics [4]. According to the case report from the Chinese Center for Disease Control and Prevention, COVID-19 patients with cardiovascular disease exhibits a highest mortality rate of $10.5 \%$ compared to those with other comorbid conditions including diabetes, chronic respiratory disease, hypertension or cancer [5]. Accumulating evidence have linked COVID-19 with raised morbidity and mortality resulting from cardiovascular disorders [6]. In this paper, we will focus on the impact of preexisting cardiovascular diseases on disease severity of COVID-19, and the cardiac complications of the diseases. Elucidation of these issues might provide significant diagnostic or prognostic value in clinical practice.

\section{Characteristics of SARS-CoV-2}

Coronaviruses (CoVs), members of the virus family Coronaviridae, are characterized as enveloped viruses with a sense and single-stranded RNA genome. CoVs, the largest known RNA viruses with genome sizes around $31 \mathrm{~kb}$, encode structural proteins including the spike $(\mathrm{S})$ protein, nucleocapsid 
$(\mathrm{N})$ protein, membrane $(\mathrm{M})$ protein, and envelope $(\mathrm{E})$ protein for viral particle production [7-9]. In addition to humans, CoVs also infect other vertebrates. On the whole, coronaviruses infecting humans (HCoVs) are divided into $\alpha$-CoVs and $\beta$-CoVs (Supplementary Table 1) $[10,11]$. Low pathogenic $\alpha$-CoVs, consisting of HCoV-229E, HCoV-OC43, HCoV-NL63 and HCoV-HKU, infect upper airways and lead to respiratory illness resembling the common cold. However, high pathogenic $\beta$-CoVs infect the lower airways and lead to bronchitis and pneumonia, which might cause lung damage and acute respiratory distress syndrome (ARDS) [12-16]. For example, the outburst of severe acute respiratory syndrome CoV (SARS-CoV) results in $9.6 \%$ mortality rate by affecting around 8400 persons [17]. The outbreak of Middle East respiratory syndrome CoV (MERS-CoV) causes 36\% mortality rate by infecting 1936 individuals [7].

COVID-19 is now affecting people globally, posing a great threat to human health and economy. COVID-19 is resulted from severe acute respiratory syndrome coronavirus 2 (SARS-CoV-2), a new member of the HCoV family. The similarity between SARS-CoV-2 and SARS-CoV which lead to the ourburst of SARS is high, around $80 \%$. Both viruses share the same cell receptor angiotensin-converting enzyme 2 (ACE2) in humans. Compared with SARS-CoV, SARSCoV-2 exhibits a more compact receptor binding domain and a higher receptor binding affinity [18]. SARS-CoV-2 infects cells by binding to cell receptor ACE2 through its $S$ protein. (Fig. 1a). The S protein of SARS-CoV-2 consists of $\mathrm{S} 1$ and $\mathrm{S} 2$ two subunits with a furin cleavage site between the subunits, mediating target cell internalization (Fig. 1b). Furin, a member of the subtilisin-like proprotein convertase family, is a membrane binding protease [19]. Furin mediates cleavage of S protein after its binding with ACE2, which is critical for viral entry into the cell [20].

\section{Viral receptor ACE2}

ACE2, first discovered to share around $60 \%$ similarity to $\mathrm{ACE}$, is an important factor in protecting the renin-angiotensin system (RAS) [21, 22]. ACE2 acts as the physiological counterbalance of ACE by converting Angiotensin I and Angiotensin II into Ang-(1-9) and Ang-(1-7), which protect the function of tissues [23]. ACE2 exists in two forms, namely soluble and membrane binding forms [24-26]. In membrane binding form of ACE2, the enzymatic motif in the transmembrane domain located on the external surface of cells. After cleavage and secretion, ACE2 exists in soluble form, which is in low concentration in the circulation system. In stress state, membrane binding form of ACE2 is cleaved by membrane-anchored metalloprotease ADAM17 (A Disintegrin And Metalloproteinase Domain-Containing Protein 17), releasing ACE2 into the circulatory system [27].
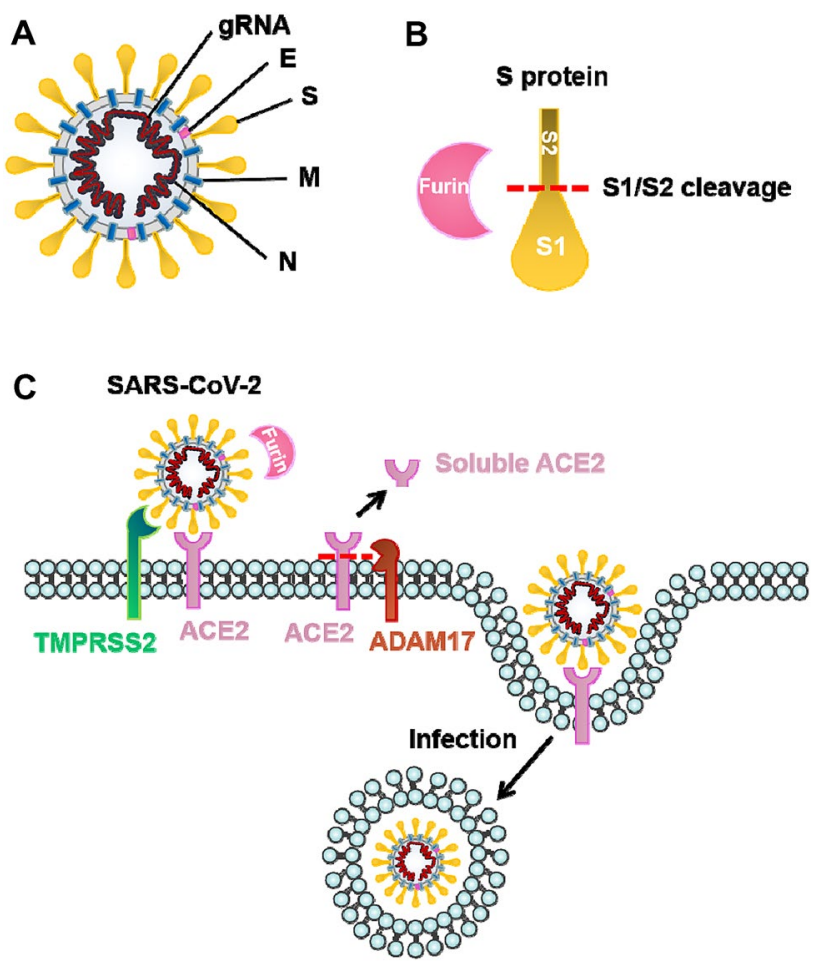

Fig. 1 Diagram of the structure of SARS-CoV-2 and viral infection. a The SARS-CoV-2 genomic RNA (gRNA) is packaged by the structural proteins consisting of the spike $(\mathrm{S})$ protein, nucleocapsid $(\mathrm{N})$ protein, membrane $(\mathrm{M})$ protein, and the envelope $(\mathrm{E})$ protein to assemble progeny virion. b Furin, which mediates cleavage of the $\mathrm{S}$ glycoprotein, is crucial in viral entry into the host cells. c SARS$\mathrm{CoV}-2$ infection is regulated by the binding of $\mathrm{S}$ protein with ACE2 on the host cells, and the cleavage of S protein by furin. ADAM17 modulates the level of ACE2 on plasma membrane, and accelerates the secretion of ACE2. The cellular serine protease TMPRSS2 also facilitates the ACE2 mediated viral entry

The role of ACE2 in circulation is undefined, although its level might be elevated in hypertension, diabetes or cardiovascular diseases [28].

ACE2, cellular receptor of SARS-CoV-2, exhibits high expression in vessel and heart which regulate circulation system, and in other organs including kidney, lung and small intestine [2]. Approaches to block viral infection like targeting ACE2 or downregulating ACE2 on cell membrane have been proposed in some studies. In vitro study has shown that recombinant protein linking the $\mathrm{Fc}$ domain of the human immunoglobulin IgG1 with ACE2 extracellular region neutralized both SARS-CoV and SARS-CoV-2 [29]. ADAM17 is highly expressed in heart and lung, and regulates ACE2 secretion [30]. It is speculated that ADAM17 elevation can promote shedding and increase soluble ACE2 level, which might inhibit the viral entry into the cells [19] (Fig. 1c). A recent study shows that SARS-CoV-2 employs ACE2 for viral infection and the cellular serine protease TMPRSS2 (Transmembrane Serine Protease 2) for S protein 
priming [31]. It is demonstrated that inhibitor of serine protease inhibits viral infection of lung cells, indicating that TMPRSS2 might act as a possible target in intervening viral infection.

\section{Cardiac disorders are presented during various CoVs infection}

Interestingly, it is described that patients with SARS show severe cardiac dysfunction [32, 33]. SARS-CoV infects the heart and regulates the level of ACE2 in a mice SARS model, indicating the important function of ACE2 in regulating viral entry into cardiac cells [34]. In heart tissues from SARS patients, viral RNA of SARS-CoV has been examined. Consistent with mice model, the presence of SARS$\mathrm{CoV}$ was also associated with decreased level of ACE2. In SARS patients, pulmonary viral infection can trigger heart infection evidenced by increased myocardial inflammation and interstitial fibrosis, leading to a more serious disease and mortality. In addition, some SARS patients were investigated and examined 12 years after infection [35]. Among various diseases that these patients experienced, around $44 \%$ had cardiovascular disorders.

A report shows that one prominent symptom of an old man infected with MERS-CoV is congestive heart failure [36]. The patient showed elevated troponin-I level, severe global left ventricular systolic dysfunction, as well as acute myocarditis evidenced by cardiovascular magnetic resonance. MERS-CoV was positive in sputum samples, while any virus known to cause myocarditis was negative. This case suggested that MERS-CoV might result in acute myocarditis and heart failure.

In addition to the cardiac disorder in humans infected with coronavirus, it has also been reported that some animal models develop myocarditis after viral infection. For example, rabbits infected with coronavirus exhibited myoctyes degeneration and necrosis, pleural effusion and congestion of the lungs and liver, and further progressed to mycarditis and congestive heart failure [37]. A study of myocarditis resulted from feline coronavirus has been published recently. Bilateral atrial expansion and left ventricular hypertrophy have been observed in the cat, which might further cause heart failure [38].

\section{Preexisting cardiovascular diseases associate with disease severity in COVID-19 patients}

A systematic analysis of 637 MERS-CoV cases suggested that patients with underlying chronic cardiovascular diseases tend to develop severe symptoms [39]. 50\% of cases show hypertension and diabetes, and around 50\% of patients present cardiovascular diseases. The increased risk of developing severe MERS-CoV in people with underlying chronic cardiovascular diseases was similarly noted for other respiration illnesses such as influenza. A number of key comorbidities are related with more severe clinical outcomes in COVID-19 patients [40]. A study of 44,672 patients recorded by the Chinese Center for Disease Control and Prevention showed that patients with cardiac diseases exhibit higher fatality rate (10.5\%) compared to overall case fatality rate $(2.3 \%)$ [5].

It has been demonstrated that patients with preexisting cardiac diseases such as hypertension, diabetes or coronary heart disease tend to develop severe symptoms in COVID19 (Table 1). We first review several major studies which qualified the disease severity by non-ICU/ ICU or survivor/ non-survivor. Although no significance was observed in the association of preexisting cardiovascular comorbidities with disease severity, which might be arisen from the small size of 41 cases in the study [41]. Another study with 138 hospital patients showed that ICU patients tend to present diabetes (8 [22.2\%] vs $6[5.9 \%])$, hypertension (21 [58.3\%] vs 22 [21.6\%]) and cardiac disease (9 [25.0\%] vs 11 [10.8\%]) compared to non-ICU patients [42]. In addition, underlying diabetes (17 [31\%] vs 19 [14\%]), hypertension (26 [48\%] vs 32 [23\%]) and cardiovascular disease (13 [24\%] vs 1 [1\%]) tend to exist in dead than living patients in another study with 197 hospital patients [1]. It has been suggested that patients with coronary heart disease or diabetes displays higher hospital mortality in univariable analysis.

Apart from the mentioned COVID-19 severity standard, a study which defined the disease severity with the American Thoracic Society guidelines has also been included [43]. Patients were divided into 926 with mild symptoms and 173 with severe symptoms according to disease severity [44]. The study displayed that severe patients were more likely to have coronary heart disease, diabetes and hypertension than non-severe patients. Besides, the COVID-19 severity was categorized as the presence of myocardial damage in other retrospective analysis. In a study with 414 cases, patients with myocardial damage were more inclined with diabetes (20 [24.4\%] vs 40 [12\%]), hypertension (49 [59.8\%] vs 78 [23.4\%]), coronary cardiac disease (24 [29.3\%] vs 20 [6.0\%]) and chronic heart failure (12 [14.6\%] vs 5 [1.5\%]) compared to those without myocardial injury [45]. A retrospective study also showed that patients with cardiac damage as shown by increased level of troponin $\mathrm{T}(\mathrm{TnT})$ were more likely to have coronary heart disease, cardiomyopathy, diabetes as well as hypertension compared to patients without myocardial injury [46].

These observations are confirmed by a study of COVID19 patients admitted to intensive care units (ICUs) of the Lombardy Region in Italy [47]. Of the 1043 patients with 
Table 1 Association of preexisting cardiovascular comorbidities in patients infected with SARS-CoV-2 according to disease severity

\begin{tabular}{|c|c|c|c|c|c|c|c|}
\hline Study & $\begin{array}{l}\text { Hospital (patient } \\
\text { number) }\end{array}$ & $\begin{array}{l}\text { Severity classifica- } \\
\text { tion }\end{array}$ & Comorbidities & Number of patients & Low severity & High severity & $\mathrm{P}$ value \\
\hline \multirow[t]{3}{*}{ Huang et al. [41] } & \multirow{3}{*}{$\begin{array}{l}\text { Jinyintan Hospital } \\
\quad(\mathrm{n}=41)\end{array}$} & \multirow[t]{3}{*}{ Non-ICU/ ICU } & Diabetes & $8(20 \%)$ & $7(25 \%)$ & $1(8 \%)$ & 0.16 \\
\hline & & & Hypertension & $6(15 \%)$ & $4(14 \%)$ & $2(15 \%)$ & 0.93 \\
\hline & & & $\begin{array}{l}\text { Cardiovascular } \\
\text { disease }\end{array}$ & $6(15 \%)$ & $3(11 \%)$ & $3(23 \%)$ & 0.32 \\
\hline \multirow[t]{3}{*}{ Wang et al. [47] } & \multirow{3}{*}{$\begin{array}{l}\text { Zhongnan Hospital } \\
\text { of Wuhan Univer- } \\
\text { sity }(n=138) \\
(n=138)\end{array}$} & \multirow[t]{3}{*}{ Non-ICU/ ICU } & Diabetes & $14(10.1 \%)$ & $6(5.9 \%)$ & $8(22.2 \%)$ & 0.009 \\
\hline & & & Hypertension & $43(31.2 \%)$ & $22(21.6 \%)$ & $21(58.3 \%)$ & $<0.001$ \\
\hline & & & $\begin{array}{l}\text { Cardiovascular } \\
\text { disease }\end{array}$ & $20(14.5 \%)$ & $11(10.8 \%)$ & $9(25.0 \%)$ & 0.04 \\
\hline \multirow[t]{3}{*}{ Zhou et al. [1] } & \multirow{3}{*}{$\begin{array}{l}\text { Jinyintan and } \\
\text { Wuhan Pulmo- } \\
\text { nary Hospital } \\
(\mathrm{n}=191)\end{array}$} & \multirow{3}{*}{$\begin{array}{l}\text { Survivor/ Non- } \\
\text { survivor }\end{array}$} & Diabetes & $36(19 \%)$ & $19(14 \%)$ & $17(31 \%)$ & 0.0051 \\
\hline & & & Hypertension & $58(30 \%)$ & $32(23 \%)$ & $26(48 \%)$ & 0.0008 \\
\hline & & & $\begin{array}{l}\text { Coronary heart } \\
\text { disease }\end{array}$ & $15(8 \%)$ & $2(1 \%)$ & $13(24 \%)$ & $<0.0001$ \\
\hline \multirow[t]{3}{*}{ Guan et al. [43] } & \multirow{3}{*}{$\begin{array}{l}552 \text { hospitals in } \\
\text { China }(\mathrm{n}=1099)\end{array}$} & \multirow[t]{3}{*}{ Nonsevere/ Severe } & Diabetes & $81(7.4 \%)$ & $53(5.7 \%)$ & $28(16.2 \%)$ & - \\
\hline & & & hypertension & $165(15.0 \%)$ & $124(13.4 \%)$ & $41(23.7 \%)$ & - \\
\hline & & & $\begin{array}{l}\text { Coronary heart } \\
\text { disease }\end{array}$ & $27(2.5 \%)$ & $17(1.8 \%)$ & $10(5.8 \%)$ & - \\
\hline \multirow[t]{4}{*}{ Shi et al. [44] } & \multirow{4}{*}{$\begin{array}{l}\text { Renmin Hospital of } \\
\text { Wuhan University } \\
(\mathrm{n}=416)\end{array}$} & \multirow{4}{*}{$\begin{array}{l}\text { Without/with car- } \\
\text { diac injury }\end{array}$} & Diabetes & $60(14.4 \%)$ & $40(12.0 \%)$ & $20(24.4 \%)$ & 0.008 \\
\hline & & & Hypertension & $127(30.5 \%)$ & $78(23.4 \%)$ & $49(59.8 \%)$ & $<0.001$ \\
\hline & & & $\begin{array}{l}\text { Coronary heart } \\
\text { disease }\end{array}$ & $44(10.6 \%)$ & $20(6.0 \%)$ & $24(29.3 \%)$ & $<0.001$ \\
\hline & & & $\begin{array}{l}\text { Chronic heart } \\
\text { failure }\end{array}$ & $17(4.1 \%)$ & $5(1.5 \%)$ & $12(14.6 \%)$ & $<0.001$ \\
\hline \multirow[t]{4}{*}{ Guo et al. [45] } & \multirow{4}{*}{$\begin{array}{l}\text { Seventh Hospital } \\
\text { of Wuhan City } \\
(n=187)\end{array}$} & \multirow{4}{*}{$\begin{array}{l}\text { Normal/ elevated } \\
\text { TnT level }\end{array}$} & Diabetes & $28(15.0 \%)$ & $12(8.9 \%)$ & $16(30.8 \%)$ & $<0.001$ \\
\hline & & & Hypertension & $61(32.6 \%)$ & $28(20.7 \%)$ & $33(63.5 \%)$ & $<0.001$ \\
\hline & & & $\begin{array}{l}\text { Coronary heart } \\
\text { disease }\end{array}$ & $21(11.2 \%)$ & $4(3 \%)$ & $17(32.7 \%)$ & $<0.001$ \\
\hline & & & Cardiomyopathy & $8(4.3 \%)$ & $0(0)$ & $8(15.4 \%)$ & $<0.001$ \\
\hline
\end{tabular}

available data, 509 (49\%) had hypertension, $223(21 \%)$ had cardiovascular disease and $180(21 \%)$ had diabetes. Among patients with hypertension, 195 (38\%) died in ICU. These data show that patients with cardiovascular diseases tend to demonstrate serious symptoms with virus infection.

\section{Myocardial injury associates with fatal outcome of COVID-19}

Although COVID-19 primarily affects lungs causing interstitial pneumonitis, in the most severe cases multiorgan failure develops, particularly the cardiovascular system. According to the reported cases by the National Health Commission of China (NHC), some SARS-CoV-2-positive patients experience cardiac signs, for example aching in the chest and stuffiness or palpitation rather than respiratory problems [2]. Indication of cardiac damage with COVID-19 was examined in five patients in Wuhan who displayed an increased level of high-sensitivity cardiac troponin I (hs-cTnI) [41]. Moreover, the cardiac injury symptom further aggravated the severity of the disease (Table 2). In another study, the expression of markers indicating cardiac damage such as creatine kinasemyocardial band (CK-MB) and hs-cTnI were dramatically increased in ICU patients than in non-ICU patients [42]. Besides, ICU patients were more tend to display arrhythmia than non-ICU patients (16 [44.4\%] vs 7 [6.9\%]), indicating that patients in high severity often have complications in cardiovascular system.

Interestingly, a cohort study showed that myocardial damage is common among patients infected with SARS-CoV-2 and is related with hospital mortality [45]. Cardiac injury occurred in $82(19.7 \%)$ of total 416 patients, and these patients demonstrated higher expression of N-terminal pro-B-type natriuretic peptide (NT-proBNP), CK-MB and hs-cTnI than those without myocardial damage. Patients with myocardial damage displayed higher mortality rate compared to those with normal cardiac function (42 [51.2\%] vs 15 [4.5\%]). Besides, patients with myocardial damage demonstrated a higher mortality rate from symptom initiation and admission to end point in a Cox regression model. Apart from respiratory failure and ARDS in COVID-19 patients, defects in cardiovascular system were the most frequently observed complications in a multicenter cohort study [1]. The frequency of cardiac injury 
Table 2 Cardiac associated outcomes in hospitalized patients with COVID-19

\begin{tabular}{|c|c|c|c|c|c|c|c|}
\hline Study & Severity classification & Cardiac disorders & All patient & Low severity & High severity & $P$ value & Biochemical markers \\
\hline Huang et al. [41] & Non-ICU/ICU & Cardiac injury & $5(12 \%)$ & $1(4 \%)$ & $4(31 \%)$ & 0.017 & $\begin{array}{l}\text { Increase in hs-cTnI } \\
\text { level in ICU } \\
\text { patients }\end{array}$ \\
\hline Wang et al. [47] & Non-ICU/ICU & $\begin{array}{l}\text { Cardiac injury } \\
\text { Arrhythmia }\end{array}$ & $\begin{array}{l}10(7.2 \%) \\
23(16.7 \%)\end{array}$ & $\begin{array}{l}2(2 \%) \\
7(6.9 \%)\end{array}$ & $\begin{array}{l}8(22.2 \%) \\
16(44.4 \%)\end{array}$ & $\begin{array}{l}<0.001 \\
<0.001\end{array}$ & $\begin{array}{l}\text { Increase in levels of } \\
\text { CK-MB, hs-cTnI, } \\
\text { d-dimer, lactate } \\
\text { dehydrogenase in } \\
\text { ICU patients }\end{array}$ \\
\hline Shi et al. [44] & $\begin{array}{l}\text { Non-survivor/ Sur- } \\
\text { vivor }\end{array}$ & Cardiac injury & $82(19.7 \%)$ & $40(11.1 \%)$ & $42(73.7 \%)$ & $<0.001$ & $\begin{array}{l}\text { Increase in levels of } \\
\text { CK-MB, hs-cTnI, } \\
\text { NT-proBNP in } \\
\text { patients with car- } \\
\text { diac injury }\end{array}$ \\
\hline Zhou et al. [1] & $\begin{array}{l}\text { Non-survivor/ Sur- } \\
\text { vivor }\end{array}$ & $\begin{array}{l}\text { Cardiac injury } \\
\text { Heart failure }\end{array}$ & $\begin{array}{l}33(17 \%) \\
44(23 \%)\end{array}$ & $\begin{array}{l}1(1 \%) \\
16(12 \%)\end{array}$ & $\begin{array}{l}32(59 \%) \\
28(52 \%)\end{array}$ & $\begin{array}{l}<0.0001 \\
<0.0001\end{array}$ & $\begin{array}{l}\text { Increase in levels of } \\
\text { creatine kinase, } \\
\text { hs-cTnI, d-dimer, } \\
\text { serum ferritin, } \\
\text { lactate dehydro- } \\
\text { genase, IL-6 in } \\
\text { non-survivors }\end{array}$ \\
\hline Guo et al. [45] & $\begin{array}{l}\text { Normal/ elevated TnT } \\
\text { level }\end{array}$ & $\begin{array}{l}\text { Ventricular tachy- } \\
\text { cardia/ventricular } \\
\text { fibrillation (VT/VF) }\end{array}$ & $11(5.9 \%)$ & $2(1.5 \%)$ & $9(17.3 \%)$ & $<0.001$ & $\begin{array}{l}\text { Increase in levels } \\
\text { of CK-MB, NT- } \\
\text { proBNP, hsCRP, } \\
\text { procalcitonin in } \\
\text { patients with myo- } \\
\text { cardial injury }\end{array}$ \\
\hline
\end{tabular}

(32 [59\%] vs $1[1 \%], \mathrm{P}<0.0001)$, heart failure $(28$ [52\%] vs 16 [12\%], $\mathrm{P}<0.0001)$ as well as the expression of CK-MB and hs-cTnI were remarkably elevated in non-survivors than survivors. Apart from the biomarkers of myocardial injury, levels of d-dimer, serum ferritin, lactate dehydrogenase and IL-6 in non-survivors were significantly increased than survived patients.

An investigation showed that cardiac damage is strikingly correlated with death outcome of COVID-19 [46]. Cardiac damage is related to abnormal cardiac function and arrhythmias. In-hospital patients with increased level of TnT tend to develop more frequent symptoms, such as arrhythmias, ventricular tachycardia/ ventricular fibrillation. The levels of cardiac biomarkers CK-MB, NT-proBNP as well as inflammatory biomarker hsCRP were markedly upregulated in cardiac injury patients than those without cardiac damage, suggesting that inflammation might act as a possible target for cardiac damage.

\section{Prognostic cardiac biomarkers in COVID-19 patients}

Many studies showed that increased levels of cardiac biomarkers including NT-proBNP, CK-MB and hs-cTnI have been detected in patients with high severity compared with patients with low severity. Among these biomakers, hs-cTnI (marker for cardiac damage) and NT-proBNP (marker for myocardial stress) are likely to be prognostic. It has been reported that initial examination of increased levels of hs-TnI and NTproBNP predicts death rate in COVID-19 patients [48]. The study including 397 patients infected with SARS-CoV-2 demonstrated that patients with elevated hs-TnI, NT-proBNP or both exhibited higher mortality rate than those with normal levels of myocardial markers. Besides, a multivariate analysis showed that concurrence increased levels of both hs-TnI and NT-proBNP might predict the all-cause mortality rate. In another study focused on the comprehensive cardiovascular characterization in COVID-19 patients, it was found that impaired cardiac function as well as elevated levels of NTproBNP and hs-TnI were linked to poor prognosis [49]. These studies indicate that the levels of hs-cTnI and NT-proBNP combined with cardiac function assessment might predict the mortality in COVID-19 patients.

\section{Potential mechanism of myocardial damage in patients infected with SARS-CoV-2}

The underlying mechanism of cardiac participation in COVID-19 are still under study. A possible mechanism is cardiac injury resulted from SARS-CoV-2 infection (Fig. 2). 
Even though there is no abundant pathological evidence, it has been suggested that viral infection might lead to fulminant myocarditis according to the analysis of clinical data [50]. A 63 years old male COVID-19 patients displayed fulminant myocarditis five days after disease initiation [51]. The patient exhibited significantly elevated levels of biomarkers associated with the function of heart including cardiac troponin 1, BNP, CK-MB, as well as depressed left ventricular ejection fraction (LVEF) and enlarged left ventricular diameter. The myocarditis occurred with a high viral load of SARS-CoV-2, suggesting that the initial examination of high viral load might be correlated with development of myocarditis. Besides, the direct evidence linking myocardial damage to cardiac localization of SARS-CoV-2 has been reported [52]. The patient started with symptoms similar to flu which degenerated into respiratory distress and cardiogenic shock. Endomyocardial biopsy revealed mild inflammation and viral particles in cardiac tissues, indicating either a viraemic stage or lung migration of infected macrophage.

It is considered that the decreased ACE2 level upon viral infection is a major contributor to the cardiac involvement in COVID-19. ACE2 acts as a key element in regulating RAS system by antagonizing ACE and decreasing Angiotensin II [53]. It has been reported that the abnormal elevation of Angiotensin II is associated with hypertension, heart failures, and lung dysfunction [54]. It has been suggested that ACE2 is crucial in SARS-mediated cardiac inflammation and injury. Viral RNA of SARS-CoV and reduced ACE protein have been examined in heart tissues from SARS patients [34]. A mice model of pulmonary infection with SARS-CoV suggested that viral infection in heart is dependent on ACE2. Intriguingly, the level of Angiotensin II in plasma from COVID-19 patients were strikingly higher than that of healthy individuals [51]. Besides, the Angiotensin II level in COVID-19 patients was closely correlated with viral load and lung damage. It is possible that ACE2 plays an important role in myocardial involvement in COVID-19 given the similarity between SARS-CoV-2 and SARS-CoV.

Noteworthy, downregulation of ACE2 would inhibit cardioprotective role of Ang-(1-7), leading to increased level of TNF $\alpha$ production $[53,55]$. As a common inflammatory cytokine, TNF $\alpha$ involved inflammatory response might lead to myocardial injury in many studies. It has been reported that increased levels of inflammatory biomarkers hsCRP and procalcitonin, and $\mathrm{TnT}$ were observed in patients with cardiovascular diseases and poor outcomes, suggesting that severe inflammatory response might act as a regulator in cardiomyocyte injury [46]. Many studies showed that patients with myocardial damage or coronary heart disease present higher hospital mortality $[1,45]$. The levels of inflammatory biomarkers including $\mathrm{d}$-dimer, serum ferritin, and IL- 6 were significantly increased in non-survivors compared to survivors, which further indicating the important role of cytokine storm in cardiac injury during SARS-CoV-2 infection.

\section{Conclusion}

COVID-19 pandemic, caused by SARS-CoV2, has posed a significant impact on global health and economy. SARS$\mathrm{CoV} 2$ infection of the host cells is regulated by cell receptor ACE2, which also contributes to cardiac injury. Cardiovascular diseases are common in COVID-19 patients, and these patients have an adverse prognosis and high risk of mortality. Besides, the elevated expression of hs-cTnI and NT-proBNP predict poor prognosis patients. The potential
Fig. 2 The potential mechanisms of cardiac damage in COVID-19 might be direct injury of cardiomyocytes by SARS-CoV2, decreased level of ACE2 upon viral infection, and inflammatory response

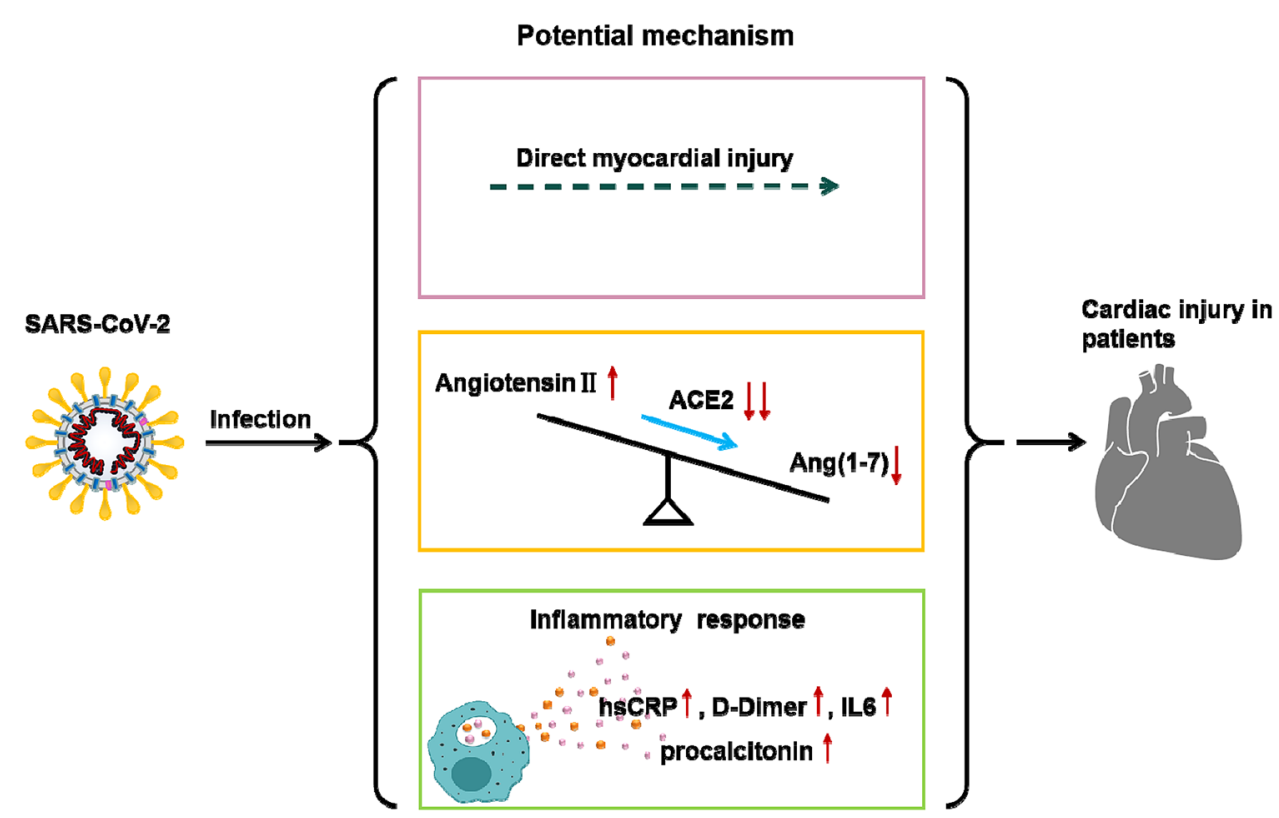


mechanisms of cardiac damage in COVID-19 could be direct injury of cardiomyocytes by SARS-CoV2, decreased level of ACE2 upon viral infection, and inflammatory response. Thus, cardiac protection should be a major consideration in the clinical treatment of COVID-19.

Acknowledgements This work was supported by grants from the National Natural Science Foundation of China Grants 81770381, Zhishan Youth Scholar Program of SEU, and the Fundamental Research Funds for the Central Universities.

Author contributions All authors contributed to the study design. Based on discussions with all authors, Dr. Xingjuan Shi drafted the manuscript, Mengying Chen draw the models and Yu Zhang organized the tables. All authors approved the final version submitted for publication.

\section{Compliance with ethical standards}

Conflict of interest The authors declare that there are no conflicts of interest.

Research involving human participants and/or animals Not applicable as this is a review article.

\section{References}

1. Zhou F, Yu T, Du R, Fan G, Liu Y, Liu Z, Xiang J, Wang Y, Song B, Gu X, Guan L, Wei Y, Li H, Wu X, Xu J, Tu S, Zhang Y, Chen H, Cao B (2020) Clinical course and risk factors for mortality of adult inpatients with COVID-19 in Wuhan, China: a retrospective cohort study. Lancet 395(10229):1054-1062. https ://doi.org/10.1016/S0140-6736(20)30566-3

2. Zheng YY, Ma YT, Zhang JY, Xie X (2020) COVID-19 and the cardiovascular system. Nat Rev Cardiol 17(5):259-260. https:// doi.org/10.1038/s41569-020-0360-5

3. Nguyen JL, Yang W, Ito K, Matte TD, Shaman J, Kinney PL (2016) Seasonal influenza infections and cardiovascular disease mortality. JAMA Cardiol 1(3):274-281. https://doi.org/10.1001/ jamacardio.2016.0433

4. Harris JE, Shah PJ, Korimilli V, Win H (2019) Frequency of troponin elevations in patients with influenza infection during the 2017-2018 influenza season. Int J Cardiol Heart Vasc 22:145147. https://doi.org/10.1016/j.ijcha.2018.12.013

5. Wu Z, McGoogan JM (2020) Characteristics of and important lessons from the coronavirus disease 2019 (COVID-19) outbreak in China: summary of a report of 72314 cases from the Chinese Center for Disease Control and Prevention. JAMA. https://doi. org/10.1001/jama.2020.2648

6. Clerkin KJ, Fried JA, Raikhelkar J, Sayer G, Griffin JM, Masoumi A, Jain SS, Burkhoff D, Kumaraiah D, Rabbani L, Schwartz A, Uriel N (2020) COVID-19 and cardiovascular disease. Circulation 141(20):1648-1655. https://doi.org/10.1161/CIRCULATIO NAHA.120.046941

7. Channappanavar R, Perlman S (2017) Pathogenic human coronavirus infections: causes and consequences of cytokine storm and immunopathology. SeminImmunopathol 39(5):529-539. https:// doi.org/10.1007/s00281-017-0629-x

8. Kim D, Lee JY, Yang JS, Kim JW, Kim VN, Chang H (2020) The architecture of SARS-CoV-2 transcriptome. Cell 181(4):914-921 e910. https://doi.org/10.1016/j.cell.2020.04.011
9. Schoeman D, Fielding BC (2019) Coronavirus envelope protein: current knowledge. Virol J 16(1):69. https://doi.org/10.1186/ s12985-019-1182-0

10. Heugel J, Martin ET, Kuypers J, Englund JA (2007) Coronavirus-associated pneumonia in previously healthy children. Pediatr Infect Dis J 26(8):753-755. https://doi.org/10.1097/ INF.0b013e318054e31b

11. Kuypers J, Martin ET, Heugel J, Wright N, Morrow R, Englund JA (2007) Clinical disease in children associated with newly described coronavirus subtypes. Pediatrics 119(1):e70-76. https ://doi.org/10.1542/peds.2006-1406

12. Drosten C, Gunther S, Preiser W, van der Werf S, Brodt HR, Becker S, Rabenau H, Panning M, Kolesnikova L, Fouchier RA, Berger A, Burguiere AM, Cinatl J, Eickmann M, Escriou N, Grywna K, Kramme S, Manuguerra JC, Muller S, Rickerts V, Sturmer M, Vieth S, Klenk HD, Osterhaus AD, Schmitz H, Doerr HW (2003) Identification of a novel coronavirus in patients with severe acute respiratory syndrome. N Engl J Med 348(20):1967-1976. https://doi.org/10.1056/NEJMoa030747

13. Kuiken T, Fouchier RA, Schutten M, Rimmelzwaan GF, van Amerongen G, van Riel D, Laman JD, de Jong T, van Doornum G, Lim W, Ling AE, Chan PK, Tam JS, Zambon MC, Gopal R, Drosten C, van der Werf S, Escriou N, Manuguerra JC, Stohr K, Peiris JS, Osterhaus AD (2003) Newly discovered coronavirus as the primary cause of severe acute respiratory syndrome. Lancet 362(9380):263-270. https://doi.org/10.1016/ S0140-6736(03)13967-0

14. Peiris JS, Lai ST, Poon LL, Guan Y, Yam LY, Lim W, Nicholls J, Yee WK, Yan WW, Cheung MT, Cheng VC, Chan KH, Tsang DN, Yung RW, Ng TK, Yuen KY, Group SS (2003) Coronavirus as a possible cause of severe acute respiratory syndrome. Lancet 361(9366):1319-1325. https://doi.org/10.1016/s0140 $-6736(03) 13077-2$

15. van Boheemen S, de Graaf M, Lauber C, Bestebroer TM, Raj VS, Zaki AM, Osterhaus AD, Haagmans BL, Gorbalenya AE, Snijder EJ, Fouchier RA (2012) Genomic characterization of a newly discovered coronavirus associated with acute respiratory distress syndrome in humans. mBio. https://doi.org/10.1128/ mBio.00473-12

16. Zaki AM, van Boheemen S, Bestebroer TM, Osterhaus AD, Fouchier RA (2012) Isolation of a novel coronavirus from a man with pneumonia in Saudi Arabia. N Engl J Med 367(19):18141820. https://doi.org/10.1056/NEJMoa1211721

17. Perlman S, Netland J (2009) Coronaviruses post-SARS: update on replication and pathogenesis. Nat Rev Microbiol 7(6):439450. https://doi.org/10.1038/nrmicro2147

18. Shang J, Ye G, Shi K, Wan Y, Luo C, Aihara H, Geng Q, Auerbach A, Li F (2020) Structural basis of receptor recognition by SARS-CoV-2. Nature 581(7807):221-224. https://doi. org/10.1038/s41586-020-2179-y

19. Rizzo P, VieceliDalla Sega F, Fortini F, Marracino L, Rapezzi C, Ferrari R (2020) COVID-19 in the heart and the lungs: could we "Notch" the inflammatory storm? Basic Res Cardiol 115(3):31. https://doi.org/10.1007/s00395-020-0791-5

20. Walls AC, Park YJ, Tortorici MA, Wall A, McGuire AT, Veesler D (2020) Structure, function, and antigenicity of the SARSCoV-2 spike glycoprotein. Cell 181(2):281-292 e286. https:// doi.org/10.1016/j.cell.2020.02.058

21. Santos RAS, Oudit GY, Verano-Braga T, Canta G, Steckelings UM, Bader M (2019) The renin-angiotensin system: going beyond the classical paradigms. Am J Physiol Heart CircPhysiol 316(5):H958-H970. https://doi.org/10.1152/ajpheart.00723 .2018

22. Bitker L, Burrell LM (2019) Classic and nonclassic renin-angiotensin systems in the critically Ill. Crit Care Clin 35(2):213-227. https://doi.org/10.1016/j.ccc.2018.11.002 
23. Santos RAS, Sampaio WO, Alzamora AC, Motta-Santos D, Alenina N, Bader M, Campagnole-Santos MJ (2018) The ACE2/ angiotensin-(1-7)/MAS axis of the renin-angiotensin system: focus on angiotensin-(1-7). Physiol Rev 98(1):505-553. https:// doi.org/10.1152/physrev.00023.2016

24. Donoghue M, Hsieh F, Baronas E, Godbout K, Gosselin M, Stagliano N, Donovan M, Woolf B, Robison K, Jeyaseelan R, Breitbart RE, Acton S (2000) A novel angiotensin-converting enzymerelated carboxypeptidase (ACE2) converts angiotensin I to angiotensin 1-9. Circ Res 87(5):E1-9. https://doi.org/10.1161/01. res.87.5.e1

25 Tipnis SR, Hooper NM, Hyde R, Karran E, Christie G, Turner AJ (2000) A human homolog of angiotensin-converting enzyme cloning and functional expression as a captopril-insensitive carboxypeptidase. J BiolChem 275(43):33238-33243. https://doi. org/10.1074/jbc.M002615200

26. Kuba K, Imai Y, Penninger JM (2013) Multiple functions of angiotensin-converting enzyme 2 and its relevance in cardiovascular diseases. Circ J 77(2):301-308. https://doi.org/10.1253/circj .cj-12-1544

27. Liu PP, Blet A, Smyth D, Li H (2020) The science underlying COVID-19: implications for the cardiovascular system. Circulation 142(1):68-78. https://doi.org/10.1161/CIRCULATIO NAHA. 120.047549

28. Turner AJ, Tipnis SR, Guy JL, Rice G, Hooper NM (2002) ACEH/ACE2 is a novel mammalian metallocarboxypeptidase and a homologue of angiotensin-converting enzyme insensitive to ACE inhibitors. Can J PhysiolPharmacol 80(4):346-353. https ://doi.org/10.1139/y02-021

29. Lei C, Qian K, Li T, Zhang S, Fu W, Ding M, Hu S (2020) Neutralization of SARS-CoV-2 spike pseudotyped virus by recombinant ACE2-Ig. Nat Commun 11(1):2070. https://doi.org/10.1038/ s41467-020-16048-4

30. Lambert DW, Yarski M, Warner FJ, Thornhill P, Parkin ET, Smith AI, Hooper NM, Turner AJ (2005) Tumor necrosis factor-alpha convertase (ADAM17) mediates regulated ectodomain shedding of the severe-acute respiratory syndrome-coronavirus (SARS$\mathrm{CoV}$ ) receptor, angiotensin-converting enzyme-2 (ACE2). J BiolChem 280(34):30113-30119. https://doi.org/10.1074/jbc.M5051 11200

31. Hoffmann M, Kleine-Weber H, Schroeder S, Kruger N, Herrler T, Erichsen S, Schiergens TS, Herrler G, Wu NH, Nitsche A, Muller MA, Drosten C, Pohlmann S (2020) SARS-CoV-2 cell entry depends on ACE2 and TMPRSS2 and is blocked by a clinically proven protease inhibitor. Cell 181(2):271-280 e278. https://doi. org/10.1016/j.cell.2020.02.052

32. Li SS, Cheng CW, Fu CL, Chan YH, Lee MP, Chan JW, Yiu SF (2003) Left ventricular performance in patients with severe acute respiratory syndrome: a 30-day echocardiographic follow-up study. Circulation 108(15):1798-1803. https://doi.org/10.1161/01. CIR.0000094737.21775.32

33. Yu CM, Wong RS, Wu EB, Kong SL, Wong J, Yip GW, Soo YO, Chiu ML, Chan YS, Hui D, Lee N, Wu A, Leung CB, Sung JJ (2006) Cardiovascular complications of severe acute respiratory syndrome. Postgrad Med J 82(964):140-144. https://doi. org/10.1136/pgmj.2005.037515

34. Oudit GY, Kassiri Z, Jiang C, Liu PP, Poutanen SM, Penninger JM, Butany J (2009) SARS-coronavirus modulation of myocardial ACE2 expression and inflammation in patients with SARS. Eur J Clin Invest 39(7):618-625. https://doi.org/10.111 $1 / \mathrm{j} .1365-2362.2009 .02153 . x$

35. Wu Q, Zhou L, Sun X, Yan Z, Hu C, Wu J, Xu L, Li X, Liu H, Yin P, Li K, Zhao J, Li Y, Wang X, Li Y, Zhang Q, Xu G, Chen $H$ (2017) Altered lipid metabolism in recovered SARS patients twelve years after infection. Sci Rep 7(1):9110. https://doi. org/10.1038/s41598-017-09536-Z
36. Alhogbani T (2016) Acute myocarditis associated with novel Middle East respiratory syndrome coronavirus. Ann Saudi Med 36(1):78-80. https://doi.org/10.5144/0256-4947.2016.78

37. Edwards S, Small JD, Geratz JD, Alexander LK, Baric RS (1992) An experimental model for myocarditis and congestive heart failure after rabbit coronavirus infection. J Infect Dis 165(1):134140. https://doi.org/10.1093/infdis/165.1.134

38. Ernandes MA, Cantoni AM, Armando F, Corradi A, Ressel L, Tamborini A (2019) Feline coronavirus-associated myocarditis in a domestic longhair cat. JFMS Open Rep 5(2):2055116919879256. https://doi.org/10.1177/2055116919 879256

39. Badawi A, Ryoo SG (2016) Prevalence of comorbidities in the Middle East respiratory syndrome coronavirus (MERS-CoV): a systematic review and meta-analysis. Int J Infect Dis 49:129-133. https://doi.org/10.1016/j.ijid.2016.06.015

40. Guzik TJ, Mohiddin SA, Dimarco A, Patel V, Savvatis K, MarelliBerg FM, Madhur MS, Tomaszewski M, Maffia P, D'Acquisto F, Nicklin SA, Marian AJ, Nosalski R, Murray EC, Guzik B, Berry C, Touyz RM, Kreutz R, Wang DW, Bhella D, Sagliocco O, Crea F, Thomson EC, McInnes IB (2020) COVID-19 and the cardiovascular system: implications for risk assessment, diagnosis, and treatment options. Cardiovasc Res. https://doi.org/10.1093/cvr/ cvaa106

41. Huang C, Wang Y, Li X, Ren L, Zhao J, Hu Y, Zhang L, Fan G, Xu J, Gu X, Cheng Z, Yu T, Xia J, Wei Y, Wu W, Xie X, Yin W, Li H, Liu M, Xiao Y, Gao H, Guo L, Xie J, Wang G, Jiang R, Gao Z, Jin Q, Wang J, Cao B (2020) Clinical features of patients infected with 2019 novel coronavirus in Wuhan, China. Lancet 395(10223):497-506. https://doi.org/10.1016/S0140 $-6736(20) 30183-5$

42. Wang D, Hu B, Hu C, Zhu F, Liu X, Zhang J, Wang B, Xiang H, Cheng Z, Xiong Y, Zhao Y, Li Y, Wang X, Peng Z (2020) Clinical characteristics of 138 hospitalized patients with 2019 novel coronavirus-infected pneumonia in Wuhan, China. JAMA. https ://doi.org/10.1001/jama.2020.1585

43. Metlay JP, Waterer GW, Long AC, Anzueto A, Brozek J, Crothers K, Cooley LA, Dean NC, Fine MJ, Flanders SA, Griffin MR, Metersky ML, Musher DM, Restrepo MI, Whitney CG (2019) Diagnosis and treatment of adults with community-acquired pneumonia. An official clinical practice guideline of the American Thoracic Society and Infectious Diseases Society of America. Am J RespirCrit Care Med 200(7):e45-e67. https://doi.org/10.1164/ rccm.201908-1581ST

44. Guan WJ, Ni ZY, Hu Y, Liang WH, Ou CQ, He JX, Liu L, Shan H, Lei CL, Hui DSC, Du B, Li LJ, Zeng G, Yuen KY, Chen RC, Tang CL, Wang T, Chen PY, Xiang J, Li SY, Wang JL, Liang ZJ, Peng YX, Wei L, Liu Y, Hu YH, Peng P, Wang JM, Liu JY, Chen Z, Li G, Zheng ZJ, Qiu SQ, Luo J, Ye CJ, Zhu SY, Zhong NS, China Medical Treatment Expert Group for C (2020) Clinical characteristics of coronavirus disease 2019 in China. N Engl J Med 382(18):1708-1720. https://doi.org/10.1056/NEJMoa2002 032

45. Shi S, Qin M, Shen B, Cai Y, Liu T, Yang F, Gong W, Liu X, Liang J, Zhao Q, Huang H, Yang B, Huang C (2020) Association of cardiac injury with mortality in hospitalized patients with COVID-19 in Wuhan, China. JAMA Cardiol. https://doi. org/10.1001/jamacardio.2020.0950

46. Guo T, Fan Y, Chen M, Wu X, Zhang L, He T, Wang H, Wan J, Wang X, Lu Z (2020) Cardiovascular implications of fatal outcomes of patients with coronavirus disease 2019 (COVID-19). JAMA Cardiol. https://doi.org/10.1001/jamacardio.2020.1017

47. Grasselli G, Zangrillo A, Zanella A, Antonelli M, Cabrini L, Castelli A, Cereda D, Coluccello A, Foti G, Fumagalli R, Iotti G, Latronico N, Lorini L, Merler S, Natalini G, Piatti A, Ranieri MV, Scandroglio AM, Storti E, Cecconi M, Pesenti A, Network C-LI, 
Nailescu A, Corona A, Zangrillo A, Protti A, Albertin A, Forastieri Molinari A, Lombardo A, Pezzi A, Benini A, Scandroglio AM, Malara A, Castelli A, Coluccello A, Micucci A, Pesenti A, Sala A, Alborghetti A, Antonini B, Capra C, Troiano C, Roscitano C, Radrizzani D, Chiumello D, Coppini D, Guzzon D, Costantini E, Malpetti E, Zoia E, Catena E, Agosteo E, Barbara E, Beretta E, Boselli E, Storti E, Harizay F, Della Mura F, Lorini FL, Donato Sigurta F, Marino F, Mojoli F, Rasulo F, Grasselli G, Casella G, De Filippi G, Castelli G, Aldegheri G, Gallioli G, Lotti G, Albano G, Landoni G, Marino G, Vitale G, Battista Perego G, Evasi G, Citerio G, Foti G, Natalini G, Merli G, Sforzini I, Bianciardi L, Carnevale L, Grazioli L, Cabrini L, Guatteri L, Salvi L, Dei Poli M, Galletti M, Gemma M, Ranucci M, Riccio M, Borelli M, Zambon M, Subert M, Cecconi M, Mazzoni MG, Raimondi M, Panigada M, Belliato M, Bronzini N, Latronico N, Petrucci N, Belgiorno N, Tagliabue P, Cortellazzi P, Gnesin P, Grosso P, Gritti P, Perazzo P, Severgnini P, Ruggeri P, Sebastiano P, Covello RD, Fernandez-Olmos R, Fumagalli R, Keim R, Rona R, Valsecchi R, Cattaneo S, Colombo S, Cirri S, Bonazzi S, Greco S, Muttini S, Langer T, Alaimo V, Viola U (2020) Baseline characteristics and outcomes of 1591 patients infected with SARS-CoV-2 admitted to ICUs of the Lombardy region, Italy. JAMA. https://doi. org/10.1001/jama.2020.5394

48. Stefanini GG, Chiarito M, Ferrante G, Cannata F, Azzolini E, Viggiani G, De Marco A, Briani M, Bocciolone M, Bragato R, Corrada E, Gasparini GL, Marconi M, Monti L, Pagnotta PA, Panico C, Pini D, Regazzoli D, My I, Kallikourdis M, Ciccarelli M, Badalamenti S, Aghemo A, Reimers B, Condorelli G, Humanitas C-TF (2020) Early detection of elevated cardiac biomarkers to optimise risk stratification in patients with COVID-19. Heart 106(19):1512-1518. https://doi.org/10.1136/heartjnl-2020-31732 2

49. Rath D, Petersen-Uribe A, Avdiu A, Witzel K, Jaeger P, Zdanyte M, Heinzmann D, Tavlaki E, Muller K, Gawaz MP (2020) Impaired cardiac function is associated with mortality in patients with acute COVID-19 infection. Clin Res Cardiol. https://doi. org/10.1007/s00392-020-01683-0

50. Ruan Q, Yang K, Wang W, Jiang L, Song J (2020) Clinical predictors of mortality due to COVID-19 based on an analysis of data of 150 patients from Wuhan, China. Intensive Care Med 46(5):846-848. https://doi.org/10.1007/s00134-020-05991-x

51. Liu Y, Yang Y, Zhang C, Huang F, Wang F, Yuan J, Wang Z, Li J, Li J, Feng C, Zhang Z, Wang L, Peng L, Chen L, Qin Y, Zhao D, Tan S, Yin L, Xu J, Zhou C, Jiang C, Liu L (2020) Clinical and biochemical indexes from 2019-nCoV infected patients linked to viral loads and lung injury. Sci China Life Sci 63(3):364-374. https://doi.org/10.1007/s11427-020-1643-8

52. Tavazzi G, Pellegrini C, Maurelli M, Belliato M, Sciutti F, Bottazzi A, Sepe PA, Resasco T, Camporotondo R, Bruno R, Baldanti F, Paolucci S, Pelenghi S, Iotti GA, Mojoli F, Arbustini E (2020) Myocardial localization of coronavirus in COVID-19 cardiogenic shock. Eur J Heart Fail 22(5):911-915. https://doi.org/10.1002/ ejhf. 1828

53. Crackower MA, Sarao R, Oudit GY, Yagil C, Kozieradzki I, Scanga SE, Oliveira-dos-Santos AJ, da Costa J, Zhang L, Pei Y, Scholey J, Ferrario CM, Manoukian AS, Chappell MC, Backx PH, Yagil Y, Penninger JM (2002) Angiotensin-converting enzyme 2 is an essential regulator of heart function. Nature 417(6891):822828. https://doi.org/10.1038/nature00786

54. Packer M, McMurray JJV (2017) Importance of endogenous compensatory vasoactive peptides in broadening the effects of inhibitors of the renin-angiotensin system for the treatment of heart failure. Lancet 389(10081):1831-1840. https://doi.org/10.1016/ S0140-6736(16)30969-2

55. Oudit GY, Kassiri Z, Patel MP, Chappell M, Butany J, Backx PH, Tsushima RG, Scholey JW, Khokha R, Penninger JM (2007) Angiotensin II-mediated oxidative stress and inflammation mediate the age-dependent cardiomyopathy in ACE2 null mice. Cardiovasc Res 75(1):29-39. https://doi.org/10.1016/j.cardiores.2007.04.007

Publisher's Note Springer Nature remains neutral with regard to jurisdictional claims in published maps and institutional affiliations. 